UDC 616.697-02:616.69-007.5

\title{
GLUTATHIONE ANTIOXIDANT PROTECTION SYSTEM IN EJACULATED SPERMATOZOA OF INFERTILE MEN WITH DIFFERENT FORMS OF PATHOSPERMIA
}

\author{
R. V. Fafula, O. K. Onufrovych, D. Z. Vorobets, \\ U. P. lefremova, Z. D. Vorobets \\ Danylo Halytsky Lviv National Medical University, 69, Pekarska St., Lviv 79010, Ukraine \\ e-mail: roman_fafula@ukr.net
}

The level of the products of lipid peroxidation measured as the thiobarbituric acid reactive substances (TBARS) and activity of enzymes of glutathione antioxidant protection system in spermatozoa were studied. It was shown that mean levels of TBARS in sperm cells of infertile men with oligozoo-, astenozoo-, oligoastenozoo- and leucocytospermia were 1.6-, 2.0-, 2.0- and 2.7-fold higher, respectively, compared with such levels in the fertile men. The glutathione peroxidase activity was decreased 2.2-fold in patients with oligozoospermia, 2.8-fold in patients with astenozoo- and oligoastenozoospermia and 3.8-fold in patients with leucocytospermia. It was found that glutathione reductase activity in patients with oligozoo-, astenozoo-, oligoastenozoo- and leucocytospermia were 2.3-, 1.6-, 1.7- and 3.3-fold lower than that in normozoospermic men, respectively. In addition, the glutathione transferase activity was decreased 1.8-2.1-fold in patients with oligozoo-, astenozoo- and oligoastenozoospermia and 5.0-fold in patients with leucocytospermia in comparison with healthy donors. The most significant changes were observed in the infertile men with leucocytospermia. This manifestation could be explained by the fact that white blood cells stimulate the formation of reactive oxygen species, induction and development of oxidative stress in sperm cells.

Keywords: antioxidant enzymes, lipid peroxidation, male infertility, pathospermia.

\section{INTRODUCTION}

Infertility is an important worldwide socio-demographic and medical-biological problem not only in Ukraine but in the most developed countries. Infertility affects approximately $15 \%$ of couples globally, and approximately $50 \%$ of infertility is caused by male factor [1]. Defective sperm function is the most common cause of male infertility [13]. Hyperproduction of Oxygen free radicals or reactive oxygen species (ROS) damage sperm cells and is considered to be as one of the mechanisms of infertility [14, 15]. It is known that animal and human spermatozoa are able to generate ROS which are important regulators of sperm functions (hyperactivation, capacitation and acrosome reaction). Spermatozoa have an unusual lipid composition of plasma membranes distinct from those of mammalian somatic cells. They are rich in polyunsaturated fatty acids and are

ISSN 1996-4536 (print) • ISSN 2311-0783 (on-line) • Біологічні Студії / Studia Biologica • 2017 • Том 11/№1 • С. 17-24 
very susceptible to be attacked by ROS $[19,20]$. ROS can modify different biomolecules including the polyunsaturated fatty acids of sperm membranes resulting in a lipid peroxidation (LPO). Thiobarbituric acid reactive substances (TBARS) is the most important marker of LPO used to monitor a degree of peroxidative damage in spermatozoa [11].

Under physiological conditions a balance between the intensity of free radical processes and the activity of antioxidant systems is maintained. When this balance is disturbed, a cellular damage arises. One of the most important enzymatic antioxidant defence mechanisms in spermatozoa consists of the glutathione system including glutathione peroxidase (GPx, EC 1.11.1.9), glutathione reductase (GR, EC 1.6.4.2) and glutathione S-transferase (GST, EC 2.5.1.18). GPx catalyzes a reduction of $\mathrm{H}_{2} \mathrm{O}_{2}$ or organic hydroperoxide, using a reduced glutathione. GR stimulates the reduction of glutathione disulfide (GSSG) to reduced glutathione (GSH). GST activity is refined by the conjugation of glutathione to a wide variety of endogenous and exogenous toxic compounds [5].

Over the past few decades, many researches addressed studying the LPO, antioxidant enzymes, and their role in male infertility. Previous studies have analyzed LPO and the activity of antioxidant enzymes of glutathione system in human spermatozoa and seminal plasma of infertile men. However, results in different papers were even contradicting one another which makes it difficult to understand the current state of knowledge on that question [5, 22, 27].

The aim of present work was to determine the LPO levels expressed by TBARS and the activity of antioxidant enzymes such as glutathione peroxidase, glutathione reductase and glutathione S-transferase in sperm cells of patients with different forms of pathospermia.

\section{MATERIALS AND METHODS}

Patients. 72 infertile men with different forms of pathospermia were involved thethis study. They were recruited between January 2014 and April 2016. A detailed medical history was performed in all studied cases. Exclusion criteria: subjects currently on any medication or antioxidant supplementation were not included. In addition, subjects with infertility over 10 years, azoospermia, testicular varicocele, genital infection, chronic illness and serious systemic diseases, smokers and alcoholic men were excluded from the study because of their well-known high seminal ROS levels and decreased antioxidant activity [3].

Ejaculates from 72 infertile and 20 fertile healthy individuals were obtained. Control group consisted of 20 healthy men with somatic fertility, normozoospermia and confirmed parenthood (married for 3-10 years and have healthy 1-3 children). Semen samples were obtained by masturbation and collected into sterile containers, following 3-5 days' abstinence from sexual activity. After liquefaction at $37{ }^{\circ} \mathrm{C}$ with $5 \% \mathrm{CO}_{2}$ in air, semen samples were examined for volume, sperm concentration, $\mathrm{pH}$, morphology and motility according to World Health Organization guidelines [26]. Before turning to study, all men were aware of patient information leaflets and gave informed consent to participate in research. Terms of sample selection meet the requirements of the principles of Helsinki Declaration on protection of human rights, Convention of Europe Council on human rights and biomedicine and the provisions of laws of Ukraine. Approval for study was taken from the ethics committe of Danylo Halytsky Lviv National Medical University. All patients and healthy donors gave written informed consent to participate in research (Ethical Committee Approval, protocol No 2 from February 16, 2015).

ISSN 1996-4536 (print) • ISSN 2311-0783 (on-line) • Біологічні Студії / Studia Biologica • 2017 • Том 11/№1 • C. 17-24 
Cell preparation. Sperm cells were washed of semen plasma by 3 times centrifugation at $3,000 \mathrm{xg}$ for $10 \mathrm{~min}$ in media which contained $(\mathrm{mM}): 120 \mathrm{NaCl}, 30 \mathrm{KCl}$, 30 Hepes $(\mathrm{pH} 7.4)$. The content of total protein in the samples was determined by Lowry method using a kit from "Simko Ltd". Determination of LPO and enzyme activities was carried out in permeabilized spermatozoa. Saponin detergent in a final concentration of $0.5 \%$ was added to sperm suspension for permeabilization of sperm membranes [24].

Assay of oxidative stress parameters. The marker of LPO (TBARS) as evaluated by measuring substances reacting with thiobarbituric acid [21]. GPx activity was determined by the oxidation of glutathione [17]. GR activity was measured by the oxidation of NADPH [23]. GST was determined by the rate of conjugate in reaction with 1-chloro-2,4 dinitrobenzene, as described [10].

Statistical analysis. Experimental data were processed by methods of variation statistics using software MS Office. Differences were calculated using the $t$-Student test for independent groups, assuming $p \leq 0.05$ as the minimum significance level. The results are presented as the mean \pm standard deviation of the mean.

\section{RESULTS AND DISCUSSION}

In our previous study, we found morphological and functional semen changes in spermatozoa at excretory toxic form of men infertility that correlated with increasing LPO and decreasing of activity of glutathione antioxidant enzymes [7, 18, 25]. These results prompted further characterization biochemical features of glutathione antioxidant protection system in ejaculated spermatozoa of infertile men with different forms of pathospermia.

Semen samples from infertile men were classified according to criteria established by the WHO. According to results of semen analysis, oligozoospermia was found in 12 patients $(16.7 \%)$, astenozoospermia was detected in 17 patients $(23.6 \%)$, oligoastenozoospermia was observed in 10 patients $(13.9 \%)$. Thirty-nine $(54.2 \%)$ infertile men had leukocytes content in semen below $1.0 \cdot 10^{6} \mathrm{ml}^{-1}$, only in 33 patients (45.8\%) leukocytospermia was noted (the leukocytes content ranged from $1.0 \cdot 10^{6} \mathrm{ml}^{-1}$ to $3.0 \cdot 10^{6} \mathrm{ml}^{-1}$ ) which indicates inflammation in this group of infertile men. The mean values of the examined morphological characteristics of semen samples in control (normozoospermia) and infertile men with different forms of pathospermia are shown in Table 1.

The concentration of spermatozoa, their motility and the percentage of normal morphological forms were significantly higher in normozoospermics than in four abnormal groups. Statistically significant deviations by main parameters of spermatograms were detected in all studied groups. The most pronounced changes were observed in amount of white blood cells (WBC) in ejaculate of patients, but other spermatogram parameters in this group of patients were within the physiological norm.

LPO expressed by TBARS level in sperm cells was found to be significantly higher in four abnormal groups than in fertile group (Table 2). Our results indicate that maximum increase in TBARS level in comparison with healthy donors was in patients with leukocytospermia. TBARS is widely used as indicator of oxidative stress. Their concentration in sperm cells was increased as a result of the oxidative damage of unsaturated fatty acids induced by the imbalanced hyperproduction of ROS. Consequently, increased TBARS level indicates hyperproduction of ROS.

ISSN 1996-4536 (print) • ISSN 2311-0783 (on-line) • Біологічні Студії / Studia Biologica • 2017 • Том 11/№1 • C. 17-24 
Table 1. Main morphological characteristics of semen samples of the infertile men with different forms of pathospermia, $M \pm m, n=10-33$

Таблиця 1. Основні морфофрункціональні характеристики еякуляту інфертильних чоловіків із різними формами патоспермії, $M \pm m, n=10-33$

\begin{tabular}{|c|c|c|c|c|c|c|c|c|}
\hline \multirow{2}{*}{\multicolumn{2}{|c|}{$\begin{array}{l}\text { Investigated } \\
\text { parameters of ejaculates }\end{array}$}} & \multirow{2}{*}{\multicolumn{2}{|c|}{$\begin{array}{l}\text { Normozoo- } \\
\text { spermia }\end{array}$}} & \multicolumn{5}{|c|}{ Infertile men } \\
\hline & & & & $\begin{array}{l}\text { oligozoo } \\
\text { spermia }\end{array}$ & & $\begin{array}{l}\text { astenozoo- } \\
\text { spermia }\end{array}$ & $\begin{array}{l}\text { oligoastenozoo- } \\
\text { spermia }\end{array}$ & $\begin{array}{l}\text { leukocyto- } \\
\text { spermia }\end{array}$ \\
\hline \multicolumn{2}{|l|}{$\begin{array}{l}\text { Concentration } \\
\text { of spermatozoa, } \\
10^{6} \mathrm{ml}^{-1}\end{array}$} & \multicolumn{2}{|c|}{$50.0 \pm 6.40$} & \multicolumn{2}{|c|}{$11.95 \pm 2.35^{\star \star *}$} & $44.30 \pm 5.35$ & $9.95 \pm 1.65^{\star * *}$ & $46.40 \pm 6.20$ \\
\hline \multicolumn{2}{|l|}{$\begin{array}{l}\text { Relative number } \\
\text { of motile sperm, \% }\end{array}$} & \multicolumn{2}{|c|}{$52.86 \pm 3,22$} & \multicolumn{2}{|c|}{$42.33 \pm 4,95$} & $24.05 \pm 5.35^{\star * *}$ & $26.05 \pm 4.25^{\text {***}}$ & $42.34 \pm 3.24$ \\
\hline \multicolumn{2}{|c|}{$\begin{array}{l}\text { Number } \\
\text { of pathological forms, \% }\end{array}$} & \multicolumn{2}{|c|}{$32.8 \pm 2.8$} & \multicolumn{2}{|c|}{$39.72 \pm 3.2$} & $45.5 \pm 5.2^{*}$ & $42.7 \pm 3.2$ & $42.4 \pm 3.6$ \\
\hline \multicolumn{2}{|c|}{$\begin{array}{l}\text { Concentration } \\
\text { of WBC in the ejaculate, } \\
10^{6} \mathrm{ml}^{-1}\end{array}$} & \multicolumn{2}{|c|}{$0.28 \pm 0.06$} & \multicolumn{2}{|c|}{$0.46 \pm 0.08$} & $0.34 \pm 0.08$ & $0.44 \pm 0.09$ & $1.56 \pm 0.25^{\star * *}$ \\
\hline \multicolumn{9}{|c|}{$\begin{array}{l}\text { Hereinafter: asterisks indicate the values that significantly differ from control; }{ }^{*} p<0.05 ;{ }^{* *} p<0.01 ;{ }^{* * *} p<0.001 \\
\text { relative to the control group (normozoospermia) }\end{array}$} \\
\hline \multicolumn{9}{|c|}{$\begin{array}{ll}\text { Примітка: } & \text { тут і надалі }{ }^{*} p<0,05 ;{ }^{* *} p<0,01 ;{ }^{* * *} p<0,001 \text { стосовно величин у осіб групи контролю } \\
& \text { (нормозооспермія) }\end{array}$} \\
\hline \multirow{2}{*}{\multicolumn{9}{|c|}{$\begin{array}{l}\text { Table 2. TBARS level and activity of antioxidant enzymes of glutathione system in } \\
\text { ejaculated spermatozoa of the infertile men with different forms of pathospermia, } \\
\mathbf{M} \pm \mathbf{m}, \mathbf{n}=10-33 \\
\text { Таблиця 2. Вміст ТБК-активних продуктів і активність ензимів глутатіонової ланки } \\
\text { антиоксидантного захисту в сперматозоїдах неплідних чоловіків із різними } \\
\text { формами патоспермій, } \mathbf{M} \pm \mathrm{m}, \mathrm{n}=10-33\end{array}$}} \\
\hline & & & & & & & & \\
\hline \multirow{2}{*}{$\begin{array}{l}\text { Investigated } \\
\text { parameters in } \\
\text { spermatozoa }\end{array}$} & \multirow{2}{*}{\multicolumn{2}{|c|}{$\begin{array}{l}\text { Normozoo- } \\
\text { spermia }\end{array}$}} & \multicolumn{6}{|c|}{ Infertile men } \\
\hline & & & & $\begin{array}{l}\text { ligozoo- } \\
\text { spermia }\end{array}$ & & $\begin{array}{l}\text { tenozoo- } \\
\text { spermia }\end{array}$ & $\begin{array}{l}\text { oligoastenozoo- } \\
\text { spermia }\end{array}$ & $\begin{array}{l}\text { leukocyto- } \\
\text { spermia }\end{array}$ \\
\hline $\begin{array}{l}\text { TBARS level, } \\
\mathrm{nmol} / \mathrm{mg} \text { of protein }\end{array}$ & \multicolumn{2}{|c|}{$162.2 \pm 15.6$} & \multicolumn{2}{|c|}{$260.4 \pm 20.1^{\star * *}$} & \multicolumn{2}{|c|}{$320.2 \pm 25.2^{\star * *}$} & $315.4 \pm 45.6^{\star * *}$ & $440.8 \pm 15.6^{\star \star *}$ \\
\hline $\begin{array}{l}\text { GPx, } \\
\mu \mathrm{mol} \text { GSH} / \mathrm{min} \mathrm{mg} \\
\text { of protein }\end{array}$ & \multicolumn{2}{|c|}{$6.5 \pm 0.9$} & \multicolumn{2}{|c|}{$2.9 \pm 0.3^{* * *}$} & \multicolumn{2}{|c|}{$2.3 \pm 0.4^{* *}$} & $2.3 \pm 0.5^{\star * *}$ & $1.7 \pm 0.4^{\star * *}$ \\
\hline $\begin{array}{l}\text { GR, } \\
\text { nmol NADPH/min mg } \\
\text { of protein }\end{array}$ & \multicolumn{2}{|c|}{$0.52 \pm 0.08$} & & $23 \pm 0.05^{*}$ & & $32 \pm 0.04^{*}$ & $0.3 \pm 0.04$ & $0.16 \pm 0.03^{\star \star *}$ \\
\hline 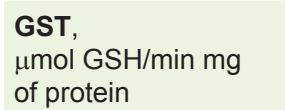 & 0.6 & $30 \pm 0,08$ & & $.34 \pm 0.06$ & & $28 \pm 0.08^{*}$ & $0.30 \pm 0.05^{*}$ & $0.12 \pm 0.05^{\star \star *}$ \\
\hline
\end{tabular}

It is known that alterations in intracellular ROS could be associated with male idiopathic infertility [16]. These results are in agreement with data of our previous publications [18] and some other studies [4, 27] also demonstrating that the increased malone-

ISSN 1996-4536 (print) • ISSN 2311-0783 (on-line) • Біологічні Студії / Studia Biologica • 2017 • Том 11/№1 • C. 17-24 
dialdehyde level (evaluated as TBARS) in semen was significantly higher in oligoasthenozoospermic and asthenozoospermic groups compared with normozoospermic group.

It is known that GPx is a key antioxidant enzyme regulating ROS levels and protecting sperm cells from LPO and oxidative stress. We showed that GPx activity was significantly decreased in patients with all forms of pathospermia compared to healthy men with normozoospermia. The activity of GR was also decreased in all studied groups of infertile men. Furthermore, GST enzyme activity was significantly decreased in patients with different forms of pathospermia. Maximum decrease in GPx, GR and GST activities were observed in patients with leukocytospermia in comparison with healthy donors.

Leukocytes are the markers of inflammation and / or presence of infection. White blood cells negatively affect sperm cells because they stimulate ROS formation of, induction and development of oxidative stress, thus, inhibiting sperm motility and functional activity [12]. In particular, it was shown [9] that ROS produced by white blood cells, cause damage of sperm DNA. Although the presence of leukocytes in semen did not diminish the in vitro fertilizing capacity of spermatozoa, the introduction of leukocytes into washed sperm preparations reduced sperm function by ROS production [2]. This finding seems paradoxic, but it indicates that seminal plasma has significant antioxidant or ROS scavenging capacity which may prevent sperm damage by the leukocytes.

There are two types of GPs: Se-dependent and Se-independent. GPx isoenzymes are interdependent; a deficit of Se-dependent form increases second isoform activity [6]. Decreased Se concentrations in seminal plasma of infertile men were accompanied by increased levels of seminal malondialdehyde of the same patients [3]. In this respect, a diminution of Se activity as an antioxidant can explain the elevated LPO in the infertile patients.

Similarly, Zhang et al. [27] reported a significantly lower GPx activity and the extent of reduction revealed a disorder-associated trend (asthenospermia < oligospermia $\approx$ oligoasthenozoospermia). By contrast, the semen disorder groups had significantly higher malondialdehyde content; the extent of this increase also revealed a disorderassociated trend (asthenospermia > oligospermia $\approx$ oligoasthenozoospermia).

It was shown that GPx-4 activity but not mRNA expression is directly related to sperm morphology (strict criteria) and is more compromised with a low percentage of normal sperm [8].

The obtained results are contradictory to findings of Dandekar et al. Who showed the increases in GPx activity in asthenozoospermic samples which represent an attempt made to overcome the reactive oxygen species [5]. Tramer et al. [22] showed that native specific activity of GPx-1, phospholipid hydroperoxide GPx (PHGPx) and GR does not differ between normo- and hypomotile human sperm samples.

GPx activity depends on the intracellular content of reduced glutathione, that is supported by GR functioning. In turn, activity of GR is determined by the level of restored nicotinamide adenine dinucleotide phosphate. Energy deficiency caused by a lack of energy substrates affects the efficiency of glutathione antioxidant protection system. That is why energy deficiency of sperm cells causes dysfunction (exhaustion) of the antioxidant protection systems.

For many years, disturbances in the prooxidant-antioxidant system have been associated with poor semen quality, however we believe that it contribution to infertility has been underestimated. In this study, we found that the levels of intracellular TBARS were

ISSN 1996-4536 (print) • ISSN 2311-0783 (on-line) • Біологічні Студії / Studia Biologica • 2017 • Том 11/№1 • С. 17-24 
elevated and the activity of glutathione antioxidant protection system (GPx, GR, GST) was decreased in the infertile individuals with different forms of pathospermia compared with healthy man with normozoospermia.

Changes in glutathione antioxidant defence system might either result from a reduced glutathione synthesis or utilization of glutathione in the detoxification process against the induced oxidative stress. The altered glutathione antioxidant defence system may ultimately affect thiol disulphide ratio or cellular proteins and their functions.

Data about sperm enzymatic antioxidant systems and male fertility potential are non-uniform [5, 22, 27]. Moreover, it is important to underline the contradictions and the controversial results published in literature. In fact, these results can be due to different reasons, for example inclusion and exclusion criteria for selection of patient, different methodologies used, lifestyle, dietary pattern and patient's origin.

It should be noted that each form of pathospermia can be characterized by certain level of oxidative stress markers (TBARS) and activity of enzymatic antioxidant systems (GPx, GR, GST). These changes indicate that in patients with pathospermia the depletion of compensatory mechanisms occurs in sperm cells.

At different pathologies associated with the infertility, the determination of these parameters may be an important tool for diagnosis, prognosis and may help in deciding on possible treatment by specific antioxidant agents. These results may be an additional prognostic criterion for confirmation of the infertility and for evaluation of treatment efficiency.

\section{CONCLUSIONS}

1. An impaired antioxidant status was found in the ejaculated spermatozoa of the infertile men.

2. The infertile group showed a significant increase in spermatozoa LPO levels and decreased GPx, GR, GST activities compared to such activities in fertile men with normozoospermia.

3. Among different forms of pathospermia, the most expressed violation in glutathione antioxidant defence system is observed in patients with leukocytospermia, probably due to up-regulated formation of ROS by white blood cells, induction and development of the oxidative stress in sperm cells.

\section{ACKNOWLEDGEMENTS}

The publication contains the results of studies conducted under President's of Ukraine grant for competitive projects (project No $\$ 63 / 97-2016$ from 10.08.2016 "Molecular biological regulatory mechanisms of disturbance of fertilizing ability spermatozoa and the development of new immuno-biochemical diagnostic methods of fertility in men" (scientific supervisor - Doc. Sci. D. Vorobets) of the State Fund for Fundamental Research.

1. Agarwal A., Mulgund A., Hamada A., Chyatte M.R. A unique view on male infertility around the globe. Reprod. Biol. Endocrinol, 2015; 13: 37.

2. Aitken R.J., West K.M., Buckingham D.W. Leoukocyte infiltration into the human ejaculate and its association with semen quality, oxidative stress, and sperm function. J. Androl, 1994; 15: 343-352.

ISSN 1996-4536 (print) • ISSN 2311-0783 (on-line) • Біологічні Студії / Studia Biologica • 2017 • Том 11/№1 • С. 17-24 
3. Atig F., Raffa M., Habib B.A. et al. Impact of seminal trace element and glutathione levels on semen quality of Tunisian infertile men. BMC Urol, 2012; $12: 6$.

4. Ben Abdallah F., Dammak I., Attia H. et al. Lipid peroxidation and antioxidant enzyme activities in infertile men: correlation with semen parameter. J. Clin. Lab. Anal, 2009; 23(2): 99-104.

5. Dandekar S.P., Nadkarni G.D., Kulkarni V.S. et al. Lipid peroxidation and antioxidant enzymes in male infertility. J. Postgrad. Med, 2002; 48(3): 186-89.

6. Deprem T., Yildiz S.E., Sari E.K. et al. Distribution of glutathione peroxidase 1 in liver tissues of healthy and diabetic rats treated with capsaisin. Biotech. Histochem, 2015; 90: 1-7.

7. Fafula R.V., Onufrovych O.K., lefremova U.P. et al. The peculiarities of arginase pathway of l-arginine in spermatozoa in men with different forms of pathospermia. Fiziol. Zh, 2016; 62(5): 83-90.

8. Garrido N., Meseguer M., Alvarez J. et al. Relationship among standard semen parameters, glutathione peroxidase/glutathione reductase activity, and mRNA expression and reduced glutathione content in ejaculated spermatozoa from fertile and infertile men. Fertil. Steril, 2004: 82(3): 1059-1066.

9. Gavriliouk D., Aitken R.J. Damage to Sperm DNA Mediated by reactive oxygen species: its impact on human reproduction and the health trajectory of offspring. Adv. Exp. Med. Biol, 2015; 868: 23-47.

10. Habig W.H., Pabst M.J., Jacoby W.B. Glutathion-S-tranferase. The first enzymatic step in mercapturic acid formation. J. Biol. Chem, 1974; 249(22): 7130-7139.

11. Januszewski A.S., Alderson N.L., Jenkins A.J. et al. Chemical modification of proteins during peroxidation of phospholipids. J. of Lipid Research, 2005; 56: 1440-1449.

12. Lackner J.E., Lakovic E., Waldhor T. et al. Spontaneous variation of leukocytospermia in asymptomatic infertile males. Fertil. Steril, 2008; 90(5): 1757-1760.

13. Lee L.K., Foo K.Y. Recent insights on the significance of transcriptomic and metabolomic analysis of male factor infertility. Clin. Biochem, 2014; 47(10-11): 973-82.

14. Mahfouz R.Z., du Plessis S.S., Aziz N. et al. Sperm viability, apoptosis, and intracellular reactive oxygen species levels in human spermatozoa before and after induction of oxidative stress. Fertil. Steril, 2010; 93(3): 814-821.

15. Makker K., Agarwal A., Sharma R. Oxidative stress and male infertility: current update. Review Article. Indian J. Med. Res, 2009; 129(4): 357-67.

16. Mayorga-Torres B.J., Camargo M., Cadavid Á.P. et al. Are oxidative stress markers associated with unexplained male infertility? Andrologia, 2016; 1-7.

17. Moin V.M.: A simple and specific method for determining glutathione peroxidase activity in erythrocytes. Lab. Delo, 1986; 12: 724-727. (In Russian).

18. Onufrovych O.K., Fafula R.V., Vorobets D.Z. State of the glutathione antioxidant system of spermatozoa at excretory toxic form infertility of men. Achievements of Clinical and Experimental Medicine, 2013; 2: 148-151.

19. Sariözkan S., Bucak M.N., Tuncer P.B. et al. Effects of different extenders and centrifugation/ washing on postthaw microscopic-oxidative stress parameters and fertilizing ability of Angora buck sperm. Theriogenology, 2010; 73(3): 316-323.

20. Shi L.-G., Yang R.-J., Yue W.-B. et al. Effect of elemental nano-selenium on semen quality, glutathione peroxidase activity, and testis ultrastructure in male Boer goats. Animal Reproduction Science, 2010; 118(2-4): 248-254.

21. Timirbulatov R., Seleznev E. Method of increase intensity of free-radical oxidization of lipid components of blood and his diagnostic value. Laboratory Business, 1981; 4: 209-211. (In Russian).

22. Tramer F, Caponecchia L., Sgrò P. et al. Native specific activity of glutathione peroxidise (GPx-1), phospholipid hydroperoxide glutathione peroxidise (PHGPx) and glutathione reductase (GR) does not differ between normo- and hypomotile human sperm samples. Int. J. Androl, 2004; 27(2): 88-93. 
23. Vlasov S.N., Shabunina E.I., Perslegina I.A. The activity of glutathione-dependent enzymes of erythrocytes in chronic liver diseases in children. Lab. Delo, 1990; 8: 19-22.

24. Vorobets $D$., Kocheshkova $N$. Infertility and erectile dysfunction men: biochemical and clinical aspects. Ternopil: Ukrmedkniga, 2008. 204 p. (In Ukrainian).

25. Vorobets D.Z., Onufrovych O.K., Fafula R.V. et al. The NO-synthase pathway of L-arginine transformation in spermatozoa of infertile men with different forms of patospermia. Exper. and Clin. Physial. and Biochem, 2016; 3(75):47-53.

26. WHO Laboratory manual for the examination of human semen and sperm-cervical mucus interaction. Cambridge University Press, 1999. 128 p.

27. Zhang W.D., Zhang Z., Jia L.T. et al. Oxygen free radicals and mitochondrial signaling in oligospermia and asthenospermia. Mol. Med. Rep, 2014; 10(4): 1875-1880.

\title{
АКТИВНІСТЬ ЕНЗИМІВ ГЛУТАТІОНОВОЇ ЛАНКИ АНТИОКСИДАНТНОГО ЗАХИСТУ ЕЯКУЛЬОВАНИХ СПЕРМАТОЗОЇДІВ НЕПЛІДНИХ ЧОЛОВІКІВ I3 РІЗНИМИ ФОРМАМИ ПАТОСПЕРМIÏ
}

\author{
Р. В. Фафула, О. К. Онуфрович, Д. З. Воробець, \\ У. П. Єфремова, З. Д. Воробець \\ Львівський національний медичний університет імені Данила Галицького \\ вул. Пекарська, 69, Львів 79010, Україна \\ e-mail:roman_fafula@ukr.net
}

Досліджено активність ензимів глутатіонової ланки антиоксидантного захисту й інтенсивність процесів пероксидного окиснення ліпідів у сперматозоїдах неплідних чоловіків із різними формами патоспермій. 3'ясовано, що середні рівні ТБКпозитивних продуктів у сперматозоїдах неплідних чоловіків з олігозоо-, астенозоо-, олігоастенозоо- і лейкоцитоспермією в 1,6-, 2,0-, 2,0- та 2,7 разу вищі, відповідно, порівняно зі здоровими чоловіками зі збереженою фертильністю. Активність глутатіонпероксидази була нижчою у 2,2 разу у пацієнтів із олігозооспермією, у 2,8 разу у пацієнтів з астенозоо- і олігоастенозооспермією і в 3,8 разу у пацієнтів із лейкоцитоспермією. Встановлено, що активність глутатіонредуктази у пацієнтів із олігозоо-, астенозоо-, олігоастенозоо- і лейкоцитоспермією у 2,3-, 1,6-, 1,7- і 3,3 разу нижча, ніж у чоловіків з нормозооспермією, відповідно. Крім того, глутатіонтрансферазна активність була нижчою в 1,8-2,1 разу у пацієнтів 3 олігозоо-, астенозооі олігоастенозооспермією та в 5,0 разу у пацієнтів з лейкоцитоспермією, порівняно зі здоровими донорами. Зниження активності ензимів глутатіонової ланки антиоксидантного захисту і зростання рівня ТБК-позитивних продуктів має найбільш виражений характер у пацієнтів із лейкоцитоспермією, що може бути зумовлено гіперпродукцією лейкоцитами реактивних фрорм кисню, індукцією та розвитком оксидативного стресу у сперматозоїдах.

Ключові слова: антиоксидантні ензими, пероксидне окиснення ліпідів, чоловіче непліддя, патоспермія.

Одержано: 13.01.2017

ISSN 1996-4536 (print) • ISSN 2311-0783 (on-line) • Біологічні Студії / Studia Biologica • 2017 • Том 11/№1 • C. 17-24 